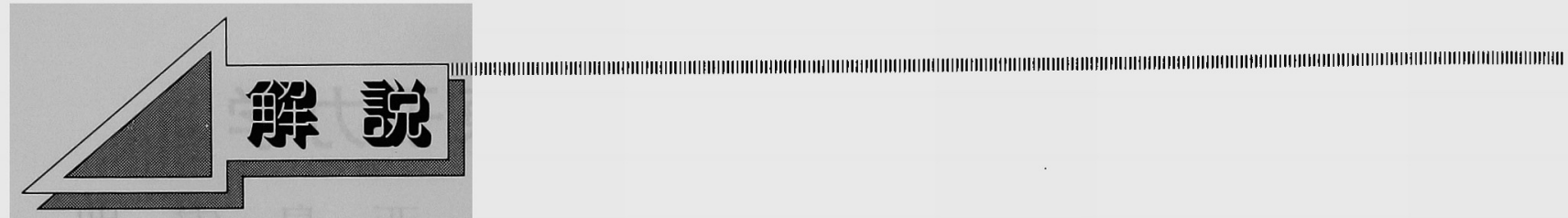

\title{
原子力発電所の事故·故障事例に対する 前兆事象評価研究の現状
}

前兆事象(ASP) 評価は, 確率諭的安全評価(PSA)手法を利用して, 原子力発電プラントで発生した事故・故障事例 の重要度を，哣心損傷事故に至る可能性の観点から，定量的に評価するための方法である。この評価は米国原子力規 制委員会(NRC)において開発・利用されているが，近年では，PSA技術の進歩に伴って評価精度が向上したこと等に より，事故·故障事例の分析·評価のみならず，PSA 結果の妥当性検討等，多方面に利用されつつある。

本稿では，筆者が 1 年間 NRCに帯在し ASP 評価に携わってきた経験を通して得た知見と，公開の文献情報を基 に, ASP評価研究の経緯と技術的内容について解説する。

\section{I. はじめに}

確率論的安全評価 (Probabilistic Safety Assessment : PSA) は, 原子力発電プラント等の施設において発生し得 る広範な事故のシナリオを見い出し，その発生頻度,進展 過程, 公衆や環境等への影響を分析·評価するものであり, 総合性と定量性に優れた手法である。1975年にWASH$1400^{(1)}$ が公表されて以来, 評価技術の進歩に伴い, 数多 くのプラントに対するPSAが実施されてきている。同時 に, PSA 手法の応用範囲む拡大しつつあり，アクシデン トマネジメント策の検討等，運転中のプラントにおける安 全管理への活用や新規プラントにおける安全設計の合理化 などに利用されてきている。PSAの根幹をなす事故シナ リオの分析およびその発生頻度の評価では，事故の発端と なる事象 (起因事象)の発生頻度やプラント内機器の故障率 等が必要となるが，これらのデー夕は，過去に発生した事 故・故障や設備の運転/作動時間等プラントの運転経験に基 づくあのである。

一方, 運転経験情報の分析・評価は, PSAに必要となる 情報を提供する以外に，分析·評価の過程やその結果から 得られる知見や教訓を安全規制やプラントの運転にフィー ドバックするという観点から，その重要性が幅広く認識さ れている。特に，米国では，運転安全(operational safety) の重要性が早くから認識され，世界に先駆けて事故·故障 データの分析・評価が始められた。この活動は，米国原子 力規制委員会 (Nuclear Regulatory Commission：NRC)が中 心となって行われているが，そこでは，技術的あるいは社

Current Status of Accident Sequence Precursor Program for Operational Events at Nuclear Power Plants: Norio WATANABE.

（1995年 11月27日 受理） 会的なインパクトを持つ一般性のある問題(generic issues) やプラント固有の問題 (plant-specific issues)を含む安全上 重要な事例を識別し，その根本原因の究明や対策の妥当性 の評価, 重要事例の傾向分析等が実施されている。この分 野においてもPSA手法が利用されている。

1978年に公表された Risk Assessment Review Group 報告書の「潜在的な重要性をもつ事故シーケンスおよび前 兆事象は $W A S H-1400$ の方法と同様の方法で評価するこ とが重要である」という結論に端を発し, 前兆事象(Accident Sequence Precursor : ASP) 評価研究がNRCに発足し た (2)。この研究は, 原子力発電プラントで発生した事故・ 故障事例の重要度を, PSA 手法を用いて, 炉心損傷に至 る可能性(当該事例が確率的にどの程度炉心損傷事故に近いむの であったか)の観点から，定量的に評価し，その結果に基づ いて各事例のランキング付けを行うというあのであり, 重 要事例の識別に有用な情報を提供する役割を果たしてい る。

このように, ASP 評価は, 事故·故障事例の分析·評価 において有効な方法であるにあかかわらず，これまで，米 国以外ではほとんど実施されていないといえる。しかし， PSA 技術が成熟したことにより評価結果の精度が向上し， また，迅速に評価が行えるようになったため，最近では， ASP 評価の用途む広がりつつある。具体的にいえば， $\mathrm{NRC}$ は, ASP 評価結果との比較を通して個別プラント評 価 (Individual Plant Examination：IPE, 各原子力発電プラント における脆弱性を把握するためにNRC が実施および結果の報告 を義務づけた PSA)で識別された事故シナリオの妥当性を チェックしたり, 従来は定性的な観点から行ってきた事例 速報のスクリーニングに適用したり，また，ASP 評価結 果を基に重要事例の傾向や原子力発電プラント全体が持っ 潜在的なリスクのトレンドを調べるという方針を打ち出し 
ている(3)。

このような背景から, 今後, ASP 評価は, 事故·故障事 例の分析において有用な情報を提供する方法として幅広く 活用されるものと予想される。

筆者は， 1 年間 NRC に滞在し ASP 評価研究に携わって きたが, 本稿では，その経験を通して得た知見と，ASP 評価に関連する文献情報を基に，ASP 評価研究の経緯扔 よび技術的内容について解説する。

\section{II. 前兆事象評価研究の概要}

はじめに，ASP 評価がどんなあのであるかについて， 蒸気発生器細管破損(SGTR) 事象を例に述べる。第 1 図 に，ASP評価モデルとして用意されているSGTR 起因の イベントッリーを示す。このイベントッリーは，最新の ASP評価モデルの基本となる“Daily Events Evaluation Manual" $^{(4)}$ に記載されているものである。このモデルで は, SGTR 発生時の事象緩和機能として，原子炬停止系 (RT)，補助給水系(AFW)，主給水系(MFW)，高圧注入系 (HPI)および余熱除去系(RHR)が，また，運転員操作と ᄂ , 均圧操作 (RCS Cooldown $<$ SG RV Setpoint), 破損側 SG 隔離(Ruptured SG Isolated)および RHR 運転圧以下への 原子炉減压(RCS Cooldown<RHR Pressure) が考慮されてい る(イベントッリーではこれらを「へディング」と呼ぶ）。各へ ディングに対してはあらかじめ失敗確率(分㞳確率)が用意 されているが, ASP評価では, 対象事例におけるプラン 卜状態(炻心損傷事故の起因となるような事象が発生したか，ま た、どの機器/系統が利用不能な状態にあったか)を表現するた めに，へディングの分岐確率を変更する。

例えば SGTR が発生した事例では, 起因事象の発生確
率を 1.0 に変更する。当該事例に扔いて, 事象緩和系や運 転員操作がすべて正常に機能した場合には，あらかじめ用 意されている分岐確率をそのまま用いてイベントッリーの 定量化が行われ，当該事例に対する条件付き炻心損傷確率 (Conditional Core Damage Probability : CCDP)が計算され る。この例では，第 1 図に示すょうに, CCDPは4.3× $10^{-4}$ 之なり,「SGTR 時均圧操作失敗(図中のシーケンス No. 405)」がドミナントシーケンスとして識別される。しかし, 美兵 2 号機の事例のように, 主蒸気隔離弁(MSIV)の不具 合が重畳した場合(美浜 2 号機の事例ではSG 隔離に際して MSIVの增し楴めが行われた)には，へディング「破損側SG嵒 離」の分岐確率を変更し CCDP の計算を行うことになる。 「破損側 SG 隔離」の分岐確率は，MSIV 等の故障による SG 隔離失敗確率 $(0.01)$ と復旧失敗確率 $(0.1)$ の積で与えられ るが，MSIV の不具合が顕在化したため前者の確率は 1.0 となり，したがって，当該事例に対する分岐確率は， 1.0 $\times 10^{-3}$ 加ら0.1に変更される。その結果, SGTRにMSIV 故障が重睤した場合のCCDPは $9.8 \times 10^{-4}$ になり、No. N05 の他に,「SGTR 時 SG 隔離失敗おょび原子炬減圧失敗 (No. 404)」と「SGTR 時 SG 隔離失敗およびRHR 不作動 (No.403)」がドミナントシーケンスと同定される。

このように, ASP 評価では, ある特定の事象に対して, 当該事象が炻心損傷事故によ゙れほど近いものであったか を, 事象を緩和する機器/系統の故障や運転員操作の失敗 を考慮しCCDPを計算することによって評価する。CCDP が大きい事象ほど潜在的リスクが高いと判断されるが、こ の值が $1.0 \times 10^{-6}$ 以上と評価された事象はASPとして識別 される(5)。したがって，ASPは，概念的には，炉心損傷 事故に対する“ニアミス”事象であり，仮に別の機器/系統

\begin{tabular}{|c|c|c|c|c|c|c|c|c|}
\hline SGTR & RT & AFW & MFW & HPI & $\begin{array}{c}\text { RCS } \\
\text { Cooldown } \\
<\text { SG RV } \\
\text { Setpoint }\end{array}$ & $\begin{array}{c}\text { Ruptured } \\
\text { SG } \\
\text { Isolated }\end{array}$ & $\begin{array}{c}\text { RCS } \\
\text { Cooldown } \\
\text { <RHR } \\
\text { Pressure }\end{array}$ & RHR \\
\hline
\end{tabular}

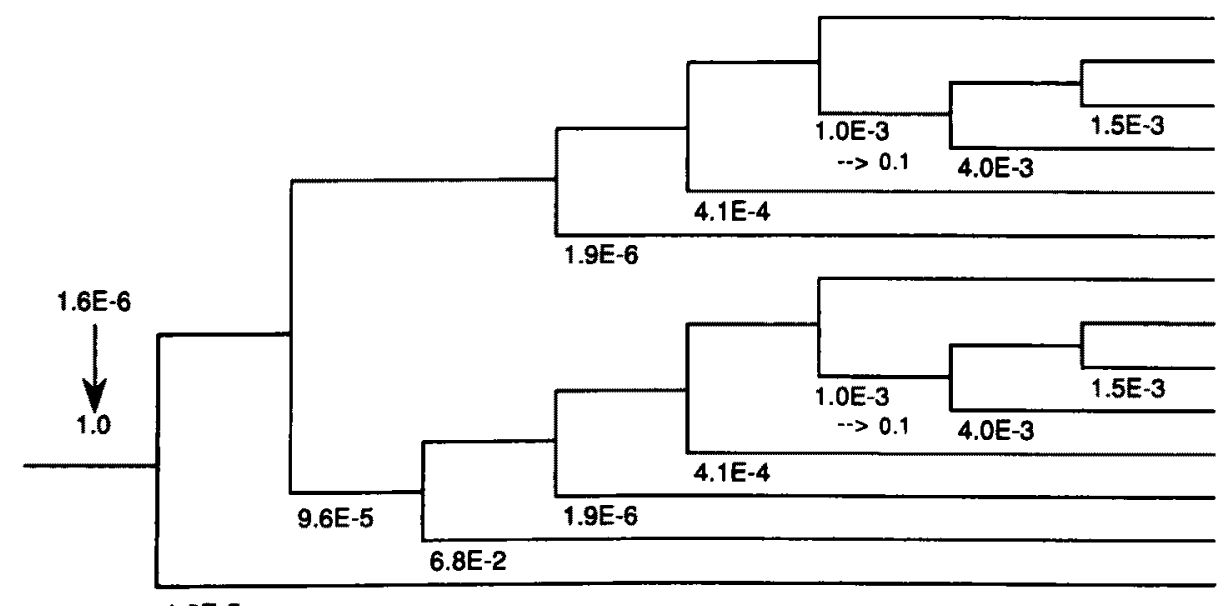

$1.0 \mathrm{E}-5$
OK 401

OK 402 CD 403 CD 404 CD 405 CD 406 OK 407 OK 408 CD 409 CD 410

第 1 图 ASP 評価におりるイベントッリーの例

$$
\begin{aligned}
& 1.5 \mathrm{E}-6->1.5 \mathrm{E}-4 \\
& 4.0 \mathrm{E}-6->4.0 \mathrm{E}-4 \\
& 4.1 \mathrm{E}-4->4.1 \mathrm{E}-4 \\
& 1.9 \mathrm{E}-6->1.9 \mathrm{E}-6 \\
& \\
& 1.3 \mathrm{E}-10->1.3 \mathrm{E}-8 \\
& 3.6 \mathrm{E}-10->3.6 \mathrm{E}-8 \\
& 3.7 \mathrm{E}-8->3.7 \mathrm{E}-8 \\
& 1.7 \mathrm{E}-10->1.7 \mathrm{E}-10 \\
& 6.5 \mathrm{E}-6->6.5 \mathrm{E}-6 \\
& \frac{1.0 \mathrm{E}-5}{4.3 \mathrm{C}-4}->\frac{1.0 \mathrm{E}-5}{9.8 \mathrm{E}-4}
\end{aligned}
$$


が故障した場合に炬心損傷に至ったと考えられる事象を指 すことになる。ASPには，(1)外部電源变失(LOOP)や冷 却材喪失 (LOCA) 等炉心損傷事故の起因事象, (2)起因事象 を緩和するために必要な系統の故障/作動不能，(3)起因事 象を楥和するために必要な複数の系統の同時機能低下，あ るいは，(4)安全系の機能低下を伴う原子炬トリップのいず れかが含まれることになる(5)。

\section{III. 前兆事象評価研究の歴史}

ASP 評価研究は, 1979年に NRC の原子力規制研究局 (Office of Nuclear Regulatory Research：RES)において開始 された。最初は，1969年から1979年までの間に発生した約 20,000件の事例を対象にASP 評価が行われ，その結果は 1982年に第 1 報 ${ }^{(6)}$ として公開された。この最初の評価で は, PWR, BWR そ执ぞについて, 給水喪失(LOFW), LOOP，小破断LOCA(SBLOCA)，蒸気管破断(SLB)の 4 種類の起因事象に対するイベントッリー・モデルが作成さ れた。このモデルは，いわゆる“generic”なあので，すべ てのPWR あるいはすべてのBWRに対して共通のイベン トッリーと分岐確率が用意された。1980 81年に発生した 事例についても同じモデルが用いられてASP評価が行わ れだ。しかし，1985年に，主担当がRESから運転デー 夕分析評価局 (Office for Analysis and Evaluation of Operational Data：AEOD)に移管され，それを機に，評価モデル の改良がなされた ${ }^{(8)}$ 。

具体的には，起因事象発生後のプラント応答の類似性か ら，PWRを 5 グループ，BWRを 3 グループに分類し，各 グループに固有のイベントッリー・モデル("plant-class specific”モデル)が構築された。また，評便対象とする起因事 象もトランジェント，LOOP， SBLOCAの 3 種類に変更さ れ，LOFWやSLBだけでなくトランジェント全般を包含 できるモデルとなった。併せてイベントッリーの分岐確率 の見直しも行われた。この改良モデルは，1984〜93年に発 生した事例の ASP 評価に用いられたが，その間にも若干 のモデル改良や分岐確率の見值しが行われている(9)。

また，1993年には，ASP 評価の幅広い利用および評価 結果の精度向上を目的として，NRCのRES，原子炉規制局 (Office of Nuclear Reactor Regulation：NRR)および AEOD が協力して評価モデルを全面的に改訂する方針が打ち出さ れ，その作業が准められているる ${ }^{(3)}$ 。の改訂では，米国で 運転中のプラント 111 基(建設中 2 基を含む)をプラント構成 の類似性から75のプラントサイトに分類し，扔のおのに対 して新たにプラント固有のASP 評価モデルが作成される こととなった。評価モデルは，従来のイベントッリーだけ に基づくものから，各プラントの系統構成の違いを反映さ れるために安全設備や電源系等のサポート系に関する フォールトッリーを作成し，イベントッリーと結合して ASP評価を行えるよう改訂されることとなった。PWRに
対しては, 従来の 3 種類のイベントッリー(トランジェント， SBLOCA, LOOP)のほかに, SGTR 起因のイベントッリー が追加された。1994年には，この新しいモデルの第 1 次版 （主として，原子炬停止系や非常用炕心冷却系など原子炬の安全 停止に直接的な役割を果たす系統，すなわち，フロントライン系 をモデル化したもの)が各プラントサイトについて作成され， 1994年に発生した事例の評価に用いられている( ${ }^{(10)}$ 。新し いモデルは，NRC が開発したPSA 用計算プログラム IRRAS ${ }^{(11)}$ を用いて作成され，実際の評価は，IRRASを ベースにしたASP 専用の計算プログラム GEMを用いて行 わ扎(10)。

ASP 評価は, 発足当初からオークリッジ国立研究所原 子力運転分析センター (Oak Ridge National Laboratory/ Nuclear Operations Analysis Center : ORNL/NOAC)で行わ れており，1982～83年を除き，1969～93年の事例に関する 評価結果が公開されている(2)(8)(9)(12) (18)。1982〜83年の事 例については，現在，サンディア国立研究所(Sandia National Laboratories : SNL)で央施されている(100。なお。こ れまでの評価により ASP と同定された事例(CCDP が1× $10^{-6}$ 以上之評価されたもの)は約 450 件である ${ }^{(2)(3)}$ 。

\section{IV. 前兆事象評価研究の現状}

\section{1. 評価手順(2)(3)}

ASP 評価手順の概要を第 2 図に示す。ASP 評価の対象 は，設置者事象報告書(Licensee Event Report：LER)とし て報告された全事例であるが，LER は年間2,000 3,000 件発行されるため, 全LERについておのおのの事象の内 容を把握するのは困難である。

そこで，まず事象内容のレビュ一対象とすべき事例を， LER の計算機データベース SCSS(Sequence Coding Search System)を利用して系統的に洗い出す作業が行われる。具 体的には, プラントの安全設備の故障や炉心損傷の起因と なり得る事象の発生あるいはその可能性のある事例が選定 される(2)。この SCSS 検索により，平均で全 LER の約 $40 \%, 1,000$ 件程度の事例が同定されることになる ${ }^{(3)}$ 。ま た，このほかに，NRCが拡大検查チーム(AIT)あるいは 事象調查チーム(IIT)を派遗した事例や，NRRによってレ ビューすべきと判断された事例等についてもその事象内容 をレビューすることになる。

次に, 識別された事例に関してLERをレビューして, さらに詳細なレビューを必要とする事例を選定する。この 選定は，いわゆる「消去法」を用いて行われ，第 2 図に示す ように, 詳細レビューの対象外となる事例を洗い出す。ま た，この際，事例自体は重要であると考えられるが， ASP詊価モデルでは解析が不可能な事例す識別されるに の種の事例については，事象の概要だけが ASP 評価報告费に揭 載される)。その結果, 詳細レビュ一の対象として, 第 1 表 


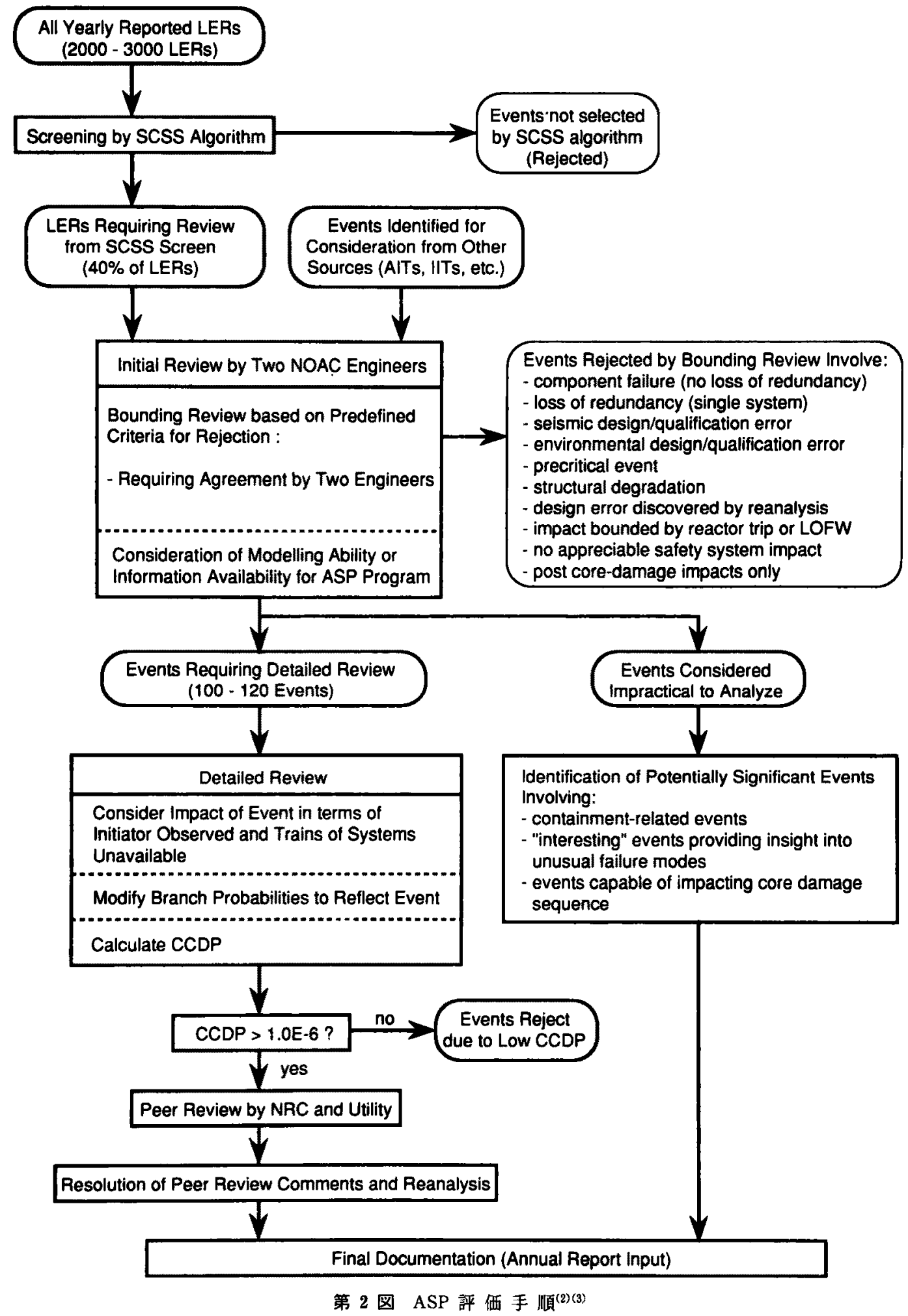

に示すような事象が同定される(2)。なお，LERのレ ビューは, ORNL/NOACスタッフ 2 人が独立して行い, 双方の意見が一致した場合にのみ, 詳細レビュー対象外事 例となる。このスクリーニングにより，100〜120件の事例 が選定される ${ }^{(3)}$ 。
詳細レビューでは，LERのほかにプラントの最終安全 解析書(FSAR)やIPE報告書等を参照し, 事象緩和系に対 する起因事象の直接的影響や機器故障および運転員過誤の 潜在的影響を考虑する。具体的には, 次の 3 つの観点から 詳細レビューが行われる(2)。 
第 1 表 典型的な詳細レビュ一対象事例(2)

- Unexpected core damage initiators (LOOP and small-break LOCA)

- All events in which reactor trip was demanded and a safety-related component failed

- All support system failures, including failures in cooling water systems, instrument air, instrumentation and control, and electric power systems

- Any event in which two or more failures occurred

- Any event or operating condition that was not predicted or that proceeded differently from the plant design basis

- Any event that, based on the reviewers' experience, could result in or significantly affected a chain of events leading to potential severe core damage

（1）出力運転中に発生した事例については，当該事例お よびその後のプラント応答によっては炬心損傷に至る か否かを検討する。

(2) プラントの運転に直接的な影響を及ぼさなかった事 例については，起因事象を想定し当該事例が事象緩和 に必要な設備の故障であるか否かを检討する。

（3）出力運転時以外の事例については, 当該事例が出力 運転時や高温停止中に発生し得るか否加を検討し, 冷 態停止中にのみ発生し得る事象である場合には崩壊熱 除去機能の継続運転に対する影響を検討する。

原則として, 詳細レビューの対象となった事例については CCDPの計算が行われるが, 中には, 詳細レビューの結 果, CCDP評洒の対象から除外される事例もある。

$\operatorname{CCDP}$ が $1 \times 10^{-6}$ 以上と評価された事例は，ASP とし て, その評価結果と事象の概要が NUREG/CR-4674に文 書化される(2)。1992年までは，ここでASP評価が終了し ていたが，1993年からは，NRCスタッフ，電力会社扰よび SNLが評価結果のレビューを行うこととなった(2)。この レビュープロセスが追加されたのは, (1)ASP 評価におけ る事象発生時のプラント状態に関する仮定が見実的でなく 評価結果が保守的になっている場合がある、(2)あらかじめ 用意されているASP評価モデルでは評価が行えない事例, 例元ば原子炻停止時の事象，等に対してその都度作成され る評価モデルの妥当性を検討する必要があるなどの理由に よる。なお、レビューコメントが提示された事例について は，再度 ASP 評価が行われ最終結果が得られる。

\section{2. 定量評価方法}

以下では，実事例に対する従来モデルおよび最新モデル によるCCDP計算例を示す。従来モデルによる計算例は, NUREG/CR-4674 Vol.19(2) を基に記述するが, 最新モデ ルによる計算例については，モデル自体が未公開であり， それを用いた ASP 評価報告書むまだ発行されていないた め，筆者が NRC 滞在中に得た知見を基に述べる。した がって，最新モデルによる計算例は概念的な記述にとどめ る。

\section{（1）評価対象事例の概要 $(2)$}

例題として，1993年 1 月に South Texas Project Unit 1 （STP-1）で発生した事例を取り上げる。この事例では,
非常用ディーゼル発電機 1 基(EDG-3)とタービン動補助 給水(TDAFW) ポンプが約 25 日間作動不能な状態に置か れており，さらに，その間の61時間は，もう 1 基(EDG2）供用から外されていた。STP-1には，3 基の EDGが 設置されており, 残りの 1 基(EDG-1)は作動可能な状態 にあった。なお，補助給水系は 4 系列から構成され，その うちの 3 系列は電動ポンプ(MDAFW-1，2，3)であり，す べて作動可能な状態にあった。

\section{（2）従来モデルによる計算}

上記の事例については，従来モデル(イベントッリー・モデ ル）用いた ASP 評価が行われており，その結果が文献(2) に記載されている。ここでは，その記載内容を基に，従来 モデルによるCCDPの計算過程について述べる。

対象事例では，25日間(597時間)にわたる EDG と TDAFW の作動不能状態が報告されているため,この状 態に対するCCDPを計算することが必要となる。STP-1 の属するブラントクラスに対して用意されている3 種類の イベントッリーのうち, 電源系がモデル化されている LOOP起因のイベントッリーを用い，当該期間中に外部電 源が要失すると仮定して ASP 評価が行われている。実際 の評価では, バッテリー負荷の切離しに成功した場合と失 敗した場合,さらに，EDG 1 基が作動不能な場合と 2 基 が作動不能な場合を考慮し，4つのケースに分けてCCDP の計算が行われている。ここでは, バッテリー負荷の切り 離しに失敗し, EDG 2 基が作動不能であった状態につい て示す。

ASP 評価で使用されたイベントッリーを第 3 図に，ま た，分岐確率を第 2 表に示す。同表に示すように，評洒に 当たっては, 起因事象(LOOP)ならびに事象時に利用不能 であった機器を含む系統, すなわち, 電源系(EP), 補助給 水系( AFW), 高圧注入系(HPI) お。さび高圧再偱環(HPR)の 分岐確率を，ちらかじめ用意されている值から変更する必 要がある。以下に, おのおのの分岐確率の計算法について 述べる。

まず，起因事象の発生確率 $P(I E)$ は，次式によって求め られる。

$$
\begin{array}{cc}
P(\mathrm{IE})= & \left(1-\exp \left(-\lambda T_{\mathrm{event}}\right)\right\} P_{\mathrm{rec}}(\mathrm{IE}) \\
\text { ここで, } & \lambda: \text { 時間当りの起因事象発生確率 } \\
T_{\text {event }} & \text { : 評価対象事例における事象継続時間 }
\end{array}
$$




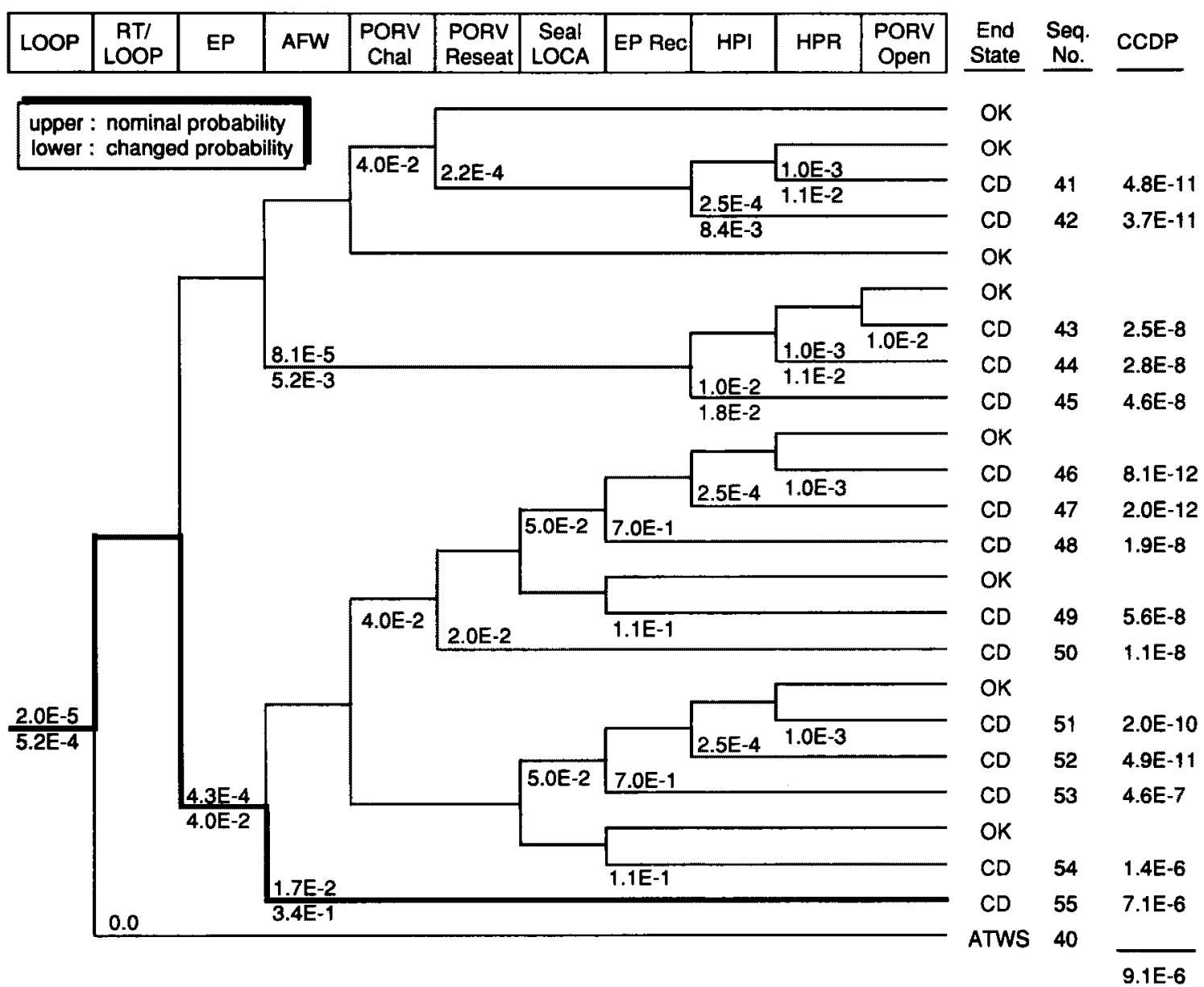

第 3 図 STP-1の事例に対する ASP 評価に用いられたイベントッリー ${ }^{(2)}$

$P_{\mathrm{rec}}$ (IE)：起因事象に対する復旧失敗確率

当該事例では，EDG 2 基および TDAFW が作動不能で あった状態が61時間であるから， $\lambda=2.0 \times 10^{-5}, T_{\text {event }}=$ $61, P_{\mathrm{rec}}(\mathrm{IE})=0.43$ として，この間に外部電源が堅失する 確率を求める。

次に, 電源系,補助給水系,高压注入系执よび高圧再循環 の分岥確率 $P(\mathrm{EP}), P(\mathrm{AFW}), P(\mathrm{HPI}), P(\mathrm{HPR})$ は, 次式に より計算される。

$$
\begin{aligned}
& P(\mathrm{EP})=P_{1}(\mathrm{EP}) P_{2}(\mathrm{EP}) P_{3}(\mathrm{EP}) P_{\mathrm{rec}}(\mathrm{EP}) \\
& P(\mathrm{AFW})=\left\{P_{1}(\mathrm{MDAFW}) P_{2}(\mathrm{MDAFW})\right. \\
& \cdot P_{3}(\mathrm{MDAFW}) P_{4}(\mathrm{TDAFW}) \\
&\left.+P_{C}(\mathrm{AFW})\right\} P_{\text {rec }}(\mathrm{AFW}) \\
& P(\mathrm{HPI})= P_{1}(\mathrm{HPI}) P_{2}(\mathrm{HPI}) P_{3}(\mathrm{HPI}) P_{\mathrm{rec}}(\mathrm{HPI}) \\
& P(\mathrm{HPR})= P_{1}(\mathrm{HPR}) P_{2}(\mathrm{HPR}) P_{3}(\mathrm{HPR}) \\
& \cdot P_{\mathrm{rec}}(\mathrm{HPR})+P_{o}(\mathrm{HPR})
\end{aligned}
$$

ここで, $P_{\mathrm{n}}$ : 系列 $\mathrm{n}(\mathrm{n}=1,2,3,4)$ の機能衰失確率

$P_{C}: A F W$ 各系列が共有する部分の機能垡失 確率

$P_{\text {rec }}:$ 系統の復旧失敗確率

$P_{0}:$ 運転員操作失敗確率

対象事例では，3 基のEDGのうちEDG-2 とEDG-3が作動
不能であったため，第 2 表に示すように，EP-2とEP-30 機能䨤失確率をそれぞれ $1.9 \times 10^{-1}, 5.7 \times 10^{-2}$ から1.0に変 更して(EP-1はEDG-1 が利用可能であったため変更する必要は ない電源系全体の機能喪失確染を求め, さらに，この值 に復旧失敗確率 (0.8)を乗ずることにより電源系に対する 分岐確率を計算する。すなわち，（2）式において， $P_{1}$ $(\mathrm{EP})=5.0 \times 10^{-2}, P_{2}(\mathrm{EP})=1.0, P_{3}(\mathrm{EP})=1.0, P_{\mathrm{rec}}(\mathrm{EP})$ $=0.8$ とすることで, $P(\mathrm{EP})=4.0 \times 10^{-2}$ が得られる。第 3 図に示すように，この值が，当該事例に対する電源系の分 岐確率として使用される。

補助給水系については，TDAFW のほかに，電源系と の関係を考慮して分岐確率を決める必要がある。すなわ ち，MDAFW-2およびMDAFW-3はそれぞれ EDG-2お よびEDG-3から動力が供給されるため，当該事例におい てはこれらのMDAFWは利用できない状態にあったこと になる。したがって，電源系が利用可能なシーケンスに対 しては，（3）式において $P_{2}(\mathrm{MDAFW})=1.0, P_{3}$ $(\mathrm{MDAFW})=1.0, P_{4}(\mathrm{TDAFW})=1.0$ として, 補助給水系 の分收確率を求め，また，イベントッリー上の電源系不作 動シーケンスに対しては， $P_{1}(\mathrm{MDAFW}) ， P_{2}(\mathrm{MDAFW})$, $P_{3}(\mathrm{MDAFW}) ， P_{4}(\mathrm{TDAFW})$ はすべて 1.0 となり，補助給 
第 2 表 STP-1 事例の ASP 評価に用いられた分岐確率 ${ }^{(2)}$

\begin{tabular}{|c|c|c|c|c|}
\hline Branch & $\begin{array}{c}\text { System } \\
\text { unavailability }\left(P_{\mathrm{n}}\right)\end{array}$ & $\begin{array}{l}\text { Nonrecovery } \\
\text { prob. }\left(P_{\text {rec }}\right)\end{array}$ & $\begin{array}{l}\text { Operator fail } \\
\text { prob. }\left(P_{0}\right) \\
\end{array}$ & $\begin{array}{c}\text { Branch } \\
\text { prob. }(P)\end{array}$ \\
\hline LOOP & $2.0 \times 10^{-5} \rightarrow 1.2 \times 10^{-3}$ & $4.3 \times 10^{-1}$ & & $5.2 \times 10^{-4}$ \\
\hline $\mathrm{RT} / \mathrm{LOOP}$ & 0.0 & 1.0 & & 0.0 \\
\hline EP & $5.4 \times 10^{-4} \rightarrow 5.0 \times 10^{-2}$ & $8.0 \times 10^{-1}$ & & $4.0 \times 10^{-2}$ \\
\hline EP-1(EDG-1) & $5.0 \times 10^{-2}$ & & & \\
\hline EP-2(EDG-2) & $5.7 \times 10^{-2} \rightarrow 1.0$ & & & \\
\hline EP-3(EDG-3) & $1.9 \times 10^{-1} \rightarrow 1.0$ & & & \\
\hline AFW & $3.1 \times 10^{-4} \rightarrow 2.0 \times 10^{-2}$ & $2.6 \times 10^{-1}$ & & $5.2 \times 10^{-3}$ \\
\hline MDAFW-1 & $2.0 \times 10^{-2}$ & & & \\
\hline MDAFW-2 & $1.0 \times 10^{-1} \rightarrow 1.0$ & & & \\
\hline MDAFW-3 & $3.0 \times 10^{-1} \rightarrow 1.0$ & & & \\
\hline TDAFW & $5.0 \times 10^{-2} \rightarrow 1.0$ & & & \\
\hline Shared Components & $2.8 \times 10^{-4}$ & & & \\
\hline $\mathrm{AFW} / \mathrm{EP}$ & $5.0 \times 10^{-2} \rightarrow 1.0$ & $3.4 \times 10^{-1}$ & & $3.4 \times 10^{-1}$ \\
\hline PORV Chal & $4.0 \times 10^{-2}$ & 1.0 & & $4.0 \times 10^{-2}$ \\
\hline PORV Reseat & $2.0 \times 10^{-2}$ & $1.1 \times 10^{-2}$ & & $2.2 \times 10^{-4}$ \\
\hline PORV Reseat/EP & $2.0 \times 10^{-2}$ & 1.0 & & $2.0 \times 10^{-2}$ \\
\hline Seal LOCA & $3.1 \times 10^{-1} \rightarrow 5.0 \times 10^{-2}$ & 1.0 & & $5.0 \times 10^{-2}$ \\
\hline EP Rec/Seal LOCA & $7.0 \times 10^{-1}$ & 1.0 & & $7.0 \times 10^{-1}$ \\
\hline EP Rec/-Seal LOCA & $1.1 \times 10^{-1}$ & 1.0 & & $1.1 \times 10^{-1}$ \\
\hline HPI & $3.0 \times 10^{-4} \rightarrow 1.0 \times 10^{-2}$ & $8.4 \times 10^{-1}$ & & $8.4 \times 10^{-3}$ \\
\hline HPI-1 & $1.0 \times 10^{-2}$ & & & \\
\hline HPI-2 & $1.0 \times 10^{-1} \rightarrow 1.0$ & & & \\
\hline HPI-3 & $3.0 \times 10^{-1} \rightarrow 1.0$ & & & \\
\hline $\mathrm{HPI}(\mathrm{F} \& \mathrm{~B})$ & $3.0 \times 10^{-4} \rightarrow 1.0 \times 10^{-2}$ & $8.4 \times 10^{-1}$ & $1.0 \times 10^{-2}$ & $1.8 \times 10^{-2}$ \\
\hline HPR & $1.5 \times 10^{-5} \rightarrow 1.0 \times 10^{-2}$ & 1.0 & $1.0 \times 10^{-3}$ & $1.1 \times 10^{-3}$ \\
\hline HPR-1 & $1.0 \times 10^{-2}$ & & & \\
\hline HPR-2 & $1.5 \times 10^{-2} \rightarrow 1.0$ & & & \\
\hline HPR -3 & $1.0 \times 10^{-1} \rightarrow 1.0$ & & - & \\
\hline PORV Open & $1.0 \times 10^{-2}$ & 1.0 & $4.0 \times 10^{-4}$ & $1.0 \times 10^{-2}$ \\
\hline
\end{tabular}

水系に対する分岐確率には TDAFW の復旧失敗確率 (0.34)が割り当てられる。

同様に，高圧注入系および高压再循環についてす，電源 系との関係を考慮して分岐確率が決められる。いずれの系 統についても，EDG-2 およびEDG-3から動力を受ける系 列は利用不能であるとして分岐確率を計算する。このよう にして決定した分岐確率を用いてイベントッリーの定量化 を行うことになる。その結果, 第 3 図に示すように、この ケースに対する CCDPは $9.1 \times 10^{-6}$ 之評洒され，ドミナン トシーケンスとして「全交流電源喪失時補助給水系不作動 (第 3 図のNo.55) 」が同定される。

\section{（3）最新モデルによる計算}

最新のモデルでは、イベントッリーのほかに、フォール トッリーを用いている。フォールトッリーは，フロントラ イン系のほかに電源系や補機冷却系等のサポート系につい ても作成されることとなっているが、現時点では，モデル の単純化等のため電源系のみがモデル化されている(19)。 プラントクラスは, 従来の 8 種から 9 種に変更されたが (BWR：従来通り 3 分類，PWR：6 分類)，イベントッリーは, プラントクラス別に作成されており，同一のプラントクラ
スに属するプラントに対しては，同じィベントッリーが用 いられる。イベントッリーの規模は，BWRにおける格納 容器ベント等のアクシデントマネジメント策やPWRにお ける 2 次系の回復等の復旧操作など最新の知見を取り入れ ており，従来モデルに比べて詳細なモデルとなっている。 その例を第 4 図に示す。第 3 図と比較すればわかるよう に,フィードアンドブリード(Bleed \& Feed)やSG冷却の 復旧(Recov SG Clg)等がへディングとして新たに追加され ている。

一方, フォールトッリーは, 各プラントの系統構成を反 映して作成され，ポンプや弁等の機器故障のほかに，自動 起動失敗時のバックアップ操作や系統の復旧操作,共通原 因故障および非常用電源と各種機器との従属性がモデル化 されている。機器故障率データや運転員の過誤率等フォー ルトッリーの定量化に必要となるデータは，過去の PSA ${ }^{(20)}$ で用いられたものを利用している(19)。フォールト ッリーは，プラントごとに35 45種類が用意され，その規 模は第 5 图に例示するように，A 4 判用紙 1 枚に印刷でき る程度のものである ${ }^{(19) 。 し か し ， こ の フ ォ ー ル ト ッ リ ー 。 ~}$ モデルでは, 第 3 表に示すように, 複数の機器故障を $1 つ$ 


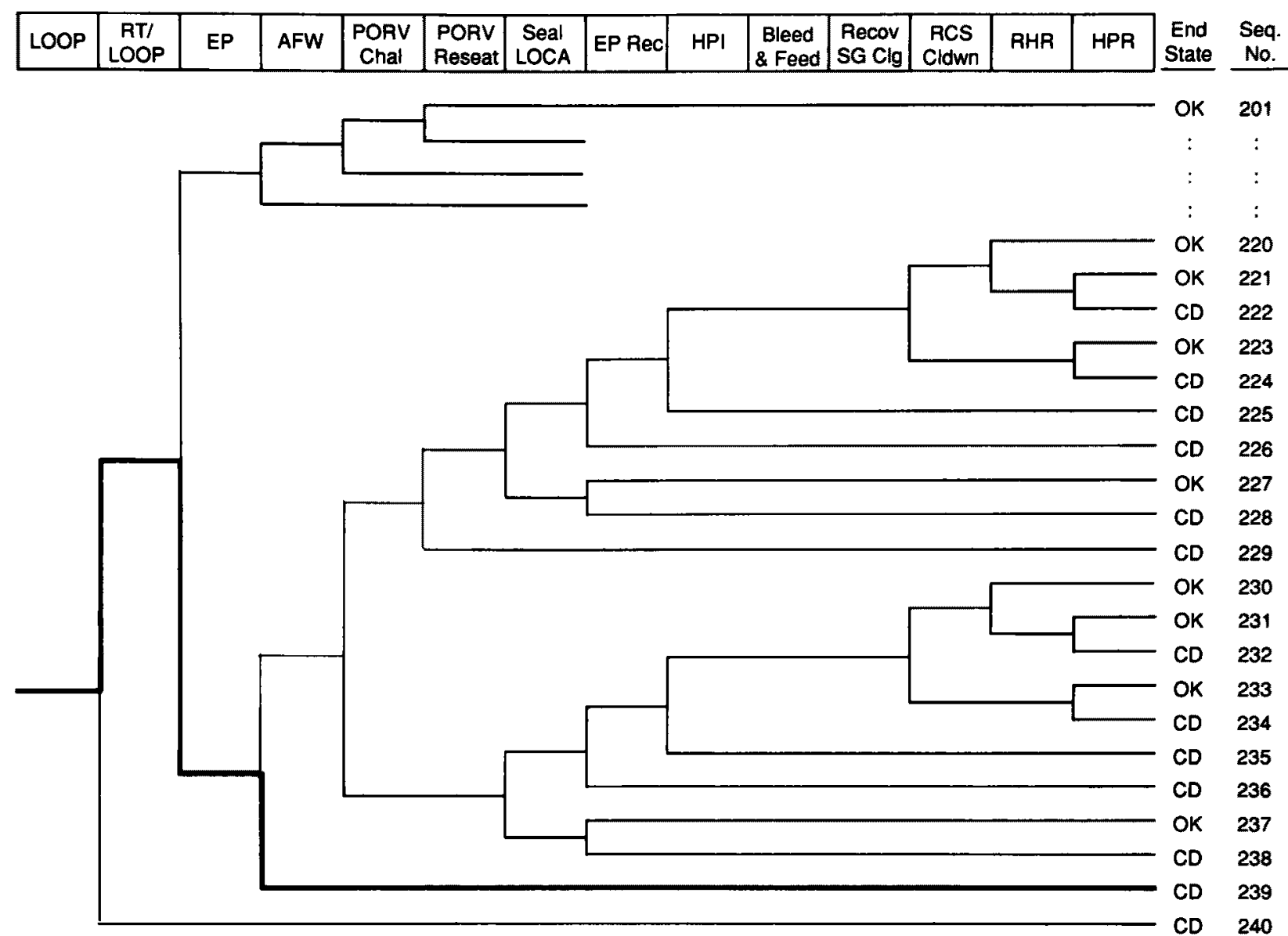

第 4 図 最新の ASP イベントッリーモデルの例(4)

の基本事象(“supercomponent”と呼ばれる)にまとめて表現 する方法が用いられている(19)。“supercomponent”には, 一般に, 直列に配置される複数の機器の故障のうち, 系統 全体に及ぼす影響が同じである機器故障がモデル化され る。“supercomponent”の採用により，計算結果にほとん ど影響しない機器故障あるいはその組合せ(フォールトッ リー解析では「カットセット」と呼ぶ济求めることなく計算が 行われるため, 計算時間が大幅に短縮されるが，計算結果 の精度は維持される。したがって，ASP評価モデルにお けるフォールトッリ一の実質的な詳細さはこれまでの PSA と逯色ないといえる。以下では，最新モデルによる CCDP計算法について, 上記（1）の事例を例に説明する。

まず, 起因事象の発生確率は, 従来モデルの場合と同様 の方法で求められる。その他のへディングに対する分岐確 率はフォールトッリーの定量化により求めることが可能で あるが，実際の CCDPの計算は，PSAにおける昵心損傷 事故の発生頻度計算と同様, イベントッリーで定義された 事故シーケンスそれぞれに対して行われる。例えば，第 4 図の事故シーケンスNo.239(全交流電源毠失時補助給水系不 作動：上記(2)でド・ントと同定されたシーケンス)について は, 起因事象であるLOOP と, 電源系および補助給水系
のフォールトッリーを“AND”ゲートで結合し全体の定量 化を行うことにより，当該シーケンスのCCDPが求められ る。しかし, この際, 対象事例における各種機器の作動状 況を考慮して、フォールトッリー上の基本事象の発生確率 を調整する必要がある。

上記 ( 1 )の事例では, EDG-2, EDG-3および TDAFW が作動不能状態にあったことから，電源系および㭪助給水 系のフォールトッリー上で, これらの機器の故障を表す基 本事象の発生確率はそれぞれ1.0と設定される。また， EDG, MDAFW とも 1 基のみ利用可能な状態にあったた ぬ, EDG 3 基の共通原因故障やMDAFW 3 基の共通原因 故障の発生確率60.0に変更される。高圧注入系や高厈再 循環についても同様の変更が行われることになる。

\section{3. 今後の計画 ${ }^{(3)}(10)$}

これまで，ASP 評価の対象は，運転中の事象に限定さ れ，炉心損傷に至る可能性という観点から行われてきた が, 最近では, 原子炉停止時の事象についてもASP評価 が行われている。しかし，停止時の事象については，その 都度 ASP 評価モデルを作成する必要があった。また，格 納容器の健全性に関わる問題は, 炬心損傷時の影響緩和あ 


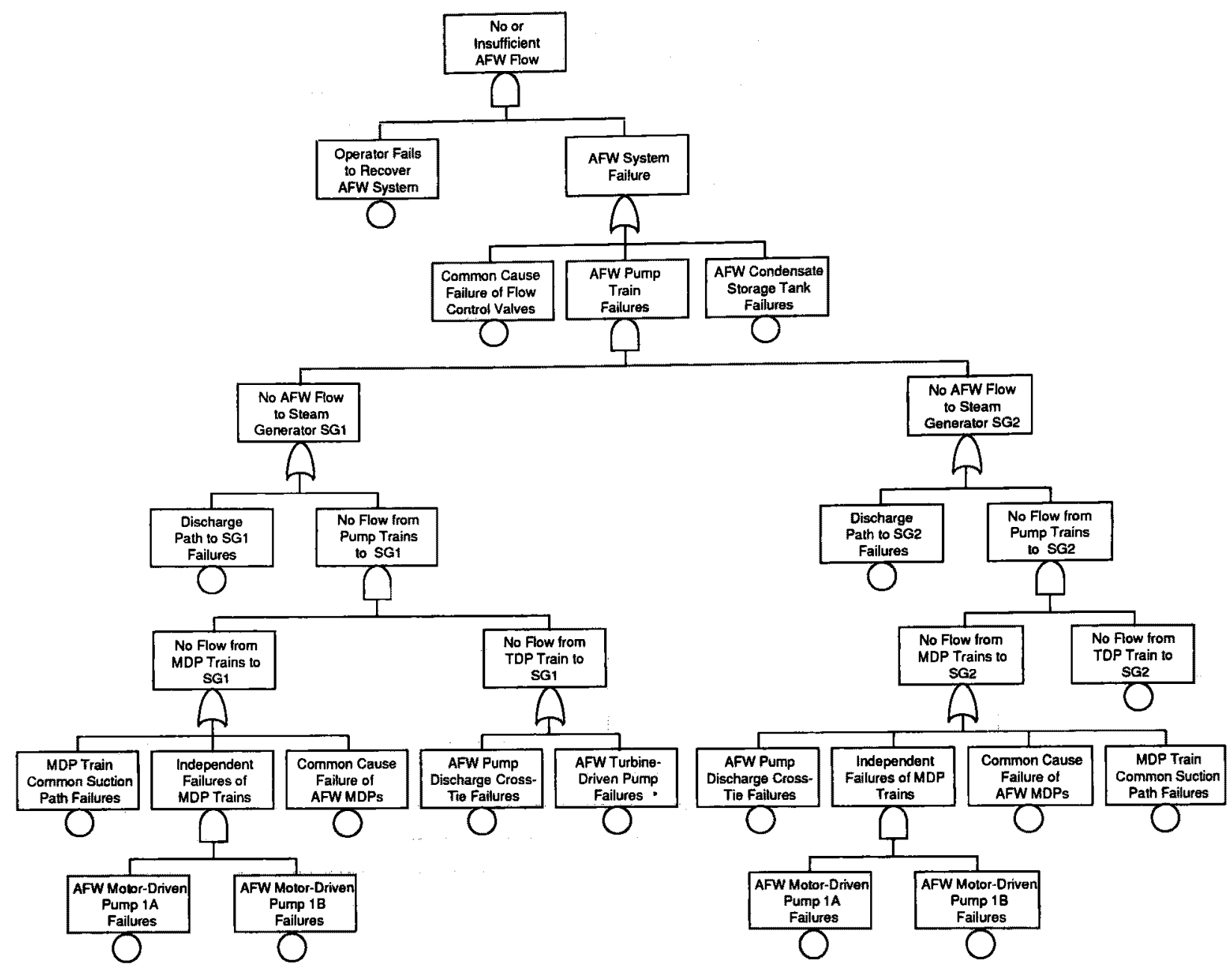

第 5 図 最新の ASP 評価モデルに扔けるフォールトッリーの例(18)

第 3 表 基本事象 “Supercomponent" の故障率の例(18)

\begin{tabular}{|c|c|c|c|c|}
\hline $\begin{array}{c}\text { Basic event } \\
\text { supercomponent }\end{array}$ & Component name & Failure mode & $\begin{array}{c}\text { Failure } \\
\text { prob. }\end{array}$ & $\begin{array}{l}\text { Basic event } \\
\text { prob. }\end{array}$ \\
\hline \multirow[t]{5}{*}{ HPI-MDP-FC-1A } & HPI MDP 1A & Fails to start & $3.0 \times 10^{-3}$ & $3.9 \times 10^{-3}$ \\
\hline & HPI MDP 1A & Fails to run & $7.2 \times 10^{-4 t}$ & \\
\hline & Discharge Check Valve & Fails to open & $1.0 \times 10^{-4}$ & \\
\hline & Suction MOV & Fails to remain open & $4.0 \times 10^{-5}$ & \\
\hline & Discharge MOV & Fails to remain open & $4.0 \times 10^{-5}$ & \\
\hline
\end{tabular}

Note: ${ }^{\dagger}$ Hourly failure probability $=3.0 \times 10^{-5} / \mathrm{h}, \quad$ Mission time $=24 \mathrm{~h}$

るいは拡大防止という側面から重要であるが, 多くの場 合，炬心損傷の直接的な要因とならないため，ASP 評価 の対象外とされてきた。しかし，格納容器の漏洩など安全 上重要と考えられる事象は，ASP評価の過程で識別され， 事例の概要が紹介されている。

NRCは，PSA と同樣，運転中の事象だけではなく，停 止時の事象やプラント外部の損乱(地祳等の外的事象)も対象 範囲にする必要があること，また，炉心損傷という観点か らだけではなく，リスクという観点からASP 評価を行う ことの必要性を鑑み，ASP評価の対象範罒を拡大する方 㻌を打ち出している。一方では, 評価結果のさらなる精度
向上を目指して，運転員操作に関する評価モデルの追加や 共通原因故障確率評価方法の変更(MGL法加ら $\alpha$ ファク夕法 に変更)等を進めている(21)。

\section{V.おわりに}

本稿では, ASP 評価の歴史おょび現状について解説し た。ASP評価は，原子力発電ブラントで発生した事故·故 障事例の重要度を, PSA 手法を用いて，炬心損傷事故に 至る可能性の観点加ら評価するための方法である。これま では，米国以外ではほとんど実施されていなかったが， PSA 技術の習熟ならびに ASP 評価の用途が広がりつつあ 
ることから、今後は幅広く利用されることが予想される。

\section{[略 語]}

AEOD : Office for Analysis and Evaluation of Operational Data, 運転データ分析評価局

AFW : Auxiliary feedwater system, 補助給水系

AIT : Augmented inspection team, 拡大检查手一ム

ASP : Accident sequence precursor, 前兆事象

BWR : Boiling water reactor, 沸騰水型原子炬

CCDP : Conditional core damage probability，条件付き炬心損 傷確率

EDG : Emergency diesel generator, 非常用ディーゼル発電機

EP : Emergency power, (非常用)電源系

FSAR : Final safety analysis report, 最終安全解析書

HPI : High pressure injection system, 高圧注入系

HPR : High pressure recirculation, 高圧再循環

IIT : Incident investigation team, 事象調查チーム

IPE : Individual plant examination, 個別プラント評価

LER：Licensee event report, 設置者事象報告書

LOCA : Loss of coolant accident, 冷却材猄失事故

LOFW : Loss of feedwater, 給水喪失

LOOP : Loss of offsite power, 外部電源品失

MDAFW : Motor-driven auxiliary feedwater, 電動補助給水系

MFW : Main feedwater system, 主給水系

MGL : Multi-greek letter, マルチグリークレター法

（共通原因故障の定量化方法の 1 つ）

MSIV : Main steam isolation valve, 主蒸気隔離弁

NRC : Nuclear Regulatory Commission, 米国原子力規制委員会

NRR : Office of Nuclear Reactor Regulation, 原子炉規制局

ORNL/NOAC : Oak Ridge National Laboratory/Nuclar Operations Analysis Center, オークリッ泪立研究所/原子 力運転分析センター

PSA : Probabilistic safety assessment, 確率諭的安全評価

PWR : Pressurized water reactor, 加圧水型原子炻

RCS : Reactor cooling system, 原子炻冷却系

RES : Office of Nuclear Regulatory Research, 原子力規制研究 局

RHR : Residual heat removal system, 余熱除去系

RT : Reactor trip system, 原子炉停止系

RV : Relief valve, 逃し升

SBLOCA : Small break loss of coolant accident, 小破断冷却材 培失事故

SG : Steam generator, 蒸気発生器
SGTR : Steam generator tube rupture, 蒸気発生器細管破損 SLB : Steam line break, 蒸気管破断

SNL : Sandia National Laboratories, サンディア国立研究所

TDAFW : Turbine-driven auxiliary feedwater, タービン動 補助給水系

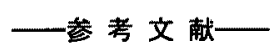

(1) USNRC : WASH-1400, (1975).

(2) Vanden Heuvel, L. N., et al. : NUREG/CR-4674, Vols. 19 \& 20, (1994).

(3) USNRC : SECY-94-076, (1994).

(4) SAIC : "Daily Events Evaluation Manual", 1-275-03-33601, (1992).

(5) 例えば, 文献(2).

(6) Minarick, J. W., et al. : NUREG/CR-2497, (1982).

(7) Cottrell, W. B., et al. : NUREG/CR-3591, Vols. 1 \& 2 (1984).

(8) Minarick, J. W., et al. : NUREG/CR-4674, Vols. 1 \& 2, (1986).

(9) Minarick, J. W., et al. : NUREG/CR-4674, Vols. $9 \& 10$, (1990).

(10) USNRC : SECY-94-268, (1994).

(11) Russell, K. D., et al. : NUREG/CR-6166, Vols. 1 \& 2, (1994).

(12) Minarick, J. W, et al. : NUREG/CR-4674, Vols. $3 \& 4$, (1987).

(13) Minarick, J. W. et al. : NUREG/CR-4674, Vols. $5 \& 6$, (1988).

(14) Minarick, J. W., et al. : NUREG/CR-4674, Vols. 7 \& 8 , (1989).

(15) Minarick, J. W., et al. : NUREG/CR-4674, Vols. 11 \& 12 , (1990).

(16) Minarick, J. W., et al. : NUREG/CR-4674, Vols. 13 \& 14 , (1991).

(17) Minarick, J. W, et al. : NUREG/CR-4674, Vols. 15 \& 16 , (1992).

(18) Copinger, D. A., et al. : NUREG/CR-4674, Vols. 17 \& 18 , (1993).

(19) Sattison, M. B., et al. : Proc. 22 nd Water Reactor Information Mtg., 359 (1994).

(20) 例えば, Drouin, M. T., et al. : NUREG /CR-4550 Vol. 1. (1987).

(21) Sattison, M. B., et al. : Proc. 22nd Water Reactor Information Mtg., 369 (1994). 